\title{
ethic@ \\ THE VIOLENCE OF THE EVENT: ONTOLOGY, ETHICS, AND POLITICS IN ZIZEK
}

\author{
A VIOLÊNCIA DO EVENTO: ONTOLOGIA, ÉTICA E POLÍTICA EM \\ ZIZEK
}

THIAGO MOTA ${ }^{1}$

(UECE/Brasil)

\begin{abstract}
The article presents the guidelines of the Slovenian philosopher Slavoj Zizek's ontology, in order to understand his unique conception of violence, as well as the respective ethical and political consequences. For him, violence is not necessarily destructive, as there is a productive form of violence: transcendental violence, which involves both breaking the coordinates and building the conditions of possibility for the emergence of a new event. However, although he came to formulate, based on the examples of Socrates, Jesus and Gandhi, the idea of a violent pacifism, Zizek does not distinguish between antagonism and agonistic and, thus, loses sight of the strategic possibility of an agonistic pacifism.
\end{abstract}

Keywords: Agonistics; Ideology; Ontological turn; Pacifism; Parallax.

\section{RESUMO}

O artigo apresenta as linhas-mestras da ontologia do filósofo esloveno Slavoj Zizek, a fim de compreender sua singular concepção de violência, bem como as respectivas consequências éticas e políticas. Para ele, a violência não é necessariamente destrutiva, pois há uma forma produtiva de violência: a violência transcendental, que implica tanto a quebra das coordenadas quanto a construção das condições de possibilidade para a emergência de um evento novo. Todavia, embora chegue a formular, com base nos exemplos de Sócrates, Jesus e Gandhi, a ideia de um pacifismo violento, Zizek não distingue entre antagonismo e agonística e, assim, perde de vista a possibilidade estratégica de um pacifismo agonístico.

Palavras-chave: Agonística; Ideologia; Reviravolta ontológica; Pacifismo; Paralaxe.

\section{Introduction}

We live in a time that claims to have supplanted all ideologies. Once highly influential, ideologies would have become outdated, that is, their pretension of validity would have expired. Both the old worldviews and the great modern narratives - enlightenment, positivism, liberalism, socialism, etc. would have become obsolete. Supposedly, we would have no more 
ideology. Postmodernity, the moment in which we have been living since, at least, the late 1970s, would be the era of post-ideology.

Postmodern and post-ideological, our time is also post-political because it is the time of a political system without politics (Rancière 2005), that is, a political system, which intends to legitimate itself suppressing all ideological disputes. Thus, the term politics no longer refers to such disputes. Sign of this is the general dislocation of the focus of the discussions in the human sciences from politics to ethics. Following the widespread extinction of the ideologies, the "ethization" of the discussions, in the academy and elsewhere, contributed to an even broader depoliticization of the agendas. Desideologized and nonpartisan, politics restricts itself to a technology of governance of private interests, albeit allegedly ethics-oriented. Nevertheless, this shift toward a new ethics (ethization of politics) lies on a deeper depoliticization of the economic sphere (economization of politics). Apparently neutral in which concerns ideology, political economy is the science that underpins the new techniques of government.

In Slavoj Zizek's words, it is as if we were "living in the end of times" (Zizek, 2011). The twilight feeling that we have come to an end is increasingly widespread. Therefore, Zizek does not stop repeating that we should take more seriously Fukuyama's (1992) thesis on "the end of history". The end of history is the end of ideologies, that is, the advent of the era of post-ideology. Giving credit to Fukuyama, we can say that the beginning of the end of history was marked by an event, the decline of the Soviet Union, whose emblematic gesture lies in the fall of the Berlin Wall. Still according to Fukuyama, with the overthrow of the Soviet socialist regime, we started to live in a stage of full hegemony of capitalism, corresponding to the global scale expansion of the neoliberal consensus, which has taken place since 1989. The generalization of this feeling that we are in the end is manifest in which, today, it is easier, or more credible, to imagine the end of the world - due to some natural, human, or even extraterrestrial catastrophe - than to imagine that capitalism can come to an end, or that another economic way could replace it.

And what about the left-wing political thought, in such an adverse context? What remains of it with the end of history? Left-wing thought shows signs of frank exhaustion, of fatigue, as well as nihilistic tendencies. How can it wake up from its post-political sleep? How can we renew its theoretical bases, so that left-wing politics can have again what to say and what to do in the current days? More specifically, how important is the notion of event in this reformulation? What role can an agonistic perspective play in this context? What kind of violence is involved in this wakening? In 
the regard to this problematic, the hypothesis of Zizek (1988) is that the alarm clock for the left-wing is the return to an old Marxist theme, the critique of ideology. However, this return presupposes, as we will see, a complete reformulation of the very concept of ideology.

\section{Ideology, fantasy, and violence}

For Zizek (2013), ideology is not a worldview nor a great narrative. Capitalism and socialism, for example, are not, in the first place, official doctrines. Zizek's concept of ideology sets itself apart from the traditional concept in two respects. On the one hand, in Zizek, ideology is a network of prejudices of various orders, moral, political, aesthetic, etc., that structure our way of thinking and acting in the everyday life, also having, of course, consequences on reality. Now, these prejudices are the coordinates, from which constitutes what is the reality for us. In this way, ideology is not what prevents or distorts our apprehension of reality. With no ideology we would have no access to reality. The mentioned coordinates are our historical a priori, they form the transcendental framework of categories, which we need to presuppose in order to get some understanding of reality, even though this same framework is modified by virtue of certain historical events. In short, we can say that ideology, according to Zizek's very particular apprehension of German idealism, is transcendental.

On the other hand, ideology is unconscious, since, for the most part, we are not aware, nor can we be, of the work of over-determination that the transcendental coordinates exert on what we think and do. To show that ideology is unconscious, Zizek launches psychoanalysis. According to him and this is his main thesis -, the psychoanalytic concept of fantasy is the direct correlate of ideology on the plan of subjective experience. For psychoanalysis, our entire experience of reality runs through a desiring filter, without which there would be no properly human or symbolic experience of reality. Therefore, fantasy is not unreal, nor an illusion, nor prevent us from having access to reality. Precisely on the contrary, it is that which enables and, at the same time, conditions our reality. Thus, reality is fantasized, desired, eroticized, metaphorized, metonimized, as psychoanalysis explains. And Zizek adds: this reality is politicized, ideologized. Synthetizing, we can say that, to the extent that it is of phantasmatic nature, ideology is unconscious.

One of the greatest innovations of Zizek's appropriation of the concept of ideology lies in the way that he thinks its relation with violence. Here, we touch on the first of the questions that we would like to highlight: the 
question of violence. Before explaining how Zizek conceives the relation between violence and ideology, we have to make a parenthesis. We are fully aware that we address the question of violence from a perspective that is unusual. For, in general, we understand violence as something negative, something destructive, something that we should deny, abolish, or eliminate. As good Christians, in general, we criticize and disapprove violence, no matter what kind of violence it may be (physical, symbolic, psychological, ideological etc.), nor what functions or purposes it may have. However, doing this we always lose the chance to understand it. As Zizek (2008, 214) writes: "to chastise outright, to condemn it as 'bad', is an ideological operation par excellence, a mystification which collaborates in rendering invisible the fundamental forms of social violence".

Therefore, the perspective that we want assume does not fall into the trap of mystification. Instead of starting with a critique of violence, the present approach presents us, without prior judgment, a certain type of violence, namely, the violence of the event, which is not simply negative, although implies a certain kind of destruction or of negation (the negation of the negation). This does not mean, in any way, that we are defending or trying to legitimize any existing violence, or apparatus of power, or political situation, where violence is in use for any purpose. On the contrary, our goal is to move beyond binarism (good versus evil), avoiding the moralization, from the beginning, of our object, which is, in the present case, violence. In other words, our goal is to develop an extra-moral consideration of violence. Assuming this perspective, we can say, perhaps too euphemistically, but that is enough to justify this proposal, that violence is not necessarily evil, although it is also not properly good. In this way, we try to contribute to the demystification or defetishization of violence. End of the parenthesis.

The point is that there is an ideological violence, which is not a violence (power) that uses series of ideas and values as an instrument of domination in the class struggle. It is not the violence contained in the violation of the law by the individual, nor the violation of individuals by the State through the law. It is not physical violence either. Rather, it is an ideological violence because it does not occur at the level of what is simply material or intra-mundane, but at the level of the coordinates that make possible and condition our reality. In this sense, ideological violence is transcendental, that is, a violence of second-order. Therefore, what is in focus here is not bloody violence, although it can be a form of violence of much greater intensity and consequences. This form of violence is radical because it does not turn against anything in the world, nor against any determinable object, but against the conditions of possibility of all 
objectivity, against the defining coordinates of reality. The destabilizing effect of this transcendental violence is a strong vertigo and a total disorientation. Indeed, the loss of references, the breakdown of coordinates and, above all, the abrupt change of point of view, with its consequences on reality, what Zizek (2007) calls parallax, is not only a form of violence; it is the greatest form of violence there can be.

\section{Trends of the ontological turn}

The breakdown of the coordinates based on which we think, speak and act, with its transcendental violence, constitutes in itself an event. As Zizek $(2014,15)$ says, an event is "the surprising emergence of something new which undermines every stable scheme". Besides transcendental, this form of violence is also eventual. Thus, a notion that needs to be analyzed, namely the notion of event, comes on the scene. We can consider the concept of event as one of the pivots from which an ontological turn (BRYANT; HARMAN; SRNICEK, 2011) succeeded the linguistic turn in the most general plan of contemporary philosophy. With this, philosophy has moved its center from language and discourse, returning to being, entities, reality, things, and objects. In the first decades of the $21^{\text {st }}$ century, we have witnessed a return to ontology and, even, to metaphysics. The discussion turns around an old question, that of the basic ontological category, of the kind of entity that a theory or discourse admits to populate the world. In other words, the question is what kind of entity does the ontology that we assume or presuppose considers to populate reality?

For classical metaphysics, there is no doubt that the basic ontological category, which we, explicitly or implicitly, but always, presuppose, is that of substance. For an ontology of substance, all the entities that populate the world are instances of a fundamental subjacent entity, precisely, a substance. The idea of substance implies that all the existent entities have fixed identities, essences, which do not change with the geographical displacement, nor with the passage of history. Although certain entities may undergo processes of actualization and, therefore, of transformation - like the seed that becomes tree or the child that becomes man -, the actual reality of every entity has already been in its essence. Substance was the fundamental metaphysical-ontological category, in ancient times, for Aristotle, but it is still at stake in the contemporary discussions. Proof of that is the very current discussion about the nature of substance: is it a substrate, a concrete particular, or an ontologically independent entity?

The use of the notion of substance as a basic ontological category has also been disputed by several philosophers, who have proposed, throughout 
history, ontologies for which movement, change, becoming are integral part of reality. This implies acknowledging either that the substantial being does not exist, so we need to find a way of thinking this non-substantial being, or that being, which is always, in one way or another, substantial, does not exist and, therefore, we need another concept to think reality. The options are not equivalent: the latter is much more radical because it implies not only a negation of substance, but also a negation of the being itself, although we maintain the pretension to formulate a kind of general theory of reality. It could be, for instance, an ontology of becoming, a theory of reality as becoming, a "becominology".

A more recent candidate for the position of the basic ontological category is the notion of bundle. Rejecting the category of substance because of its fundamental simplicity, the ontology of bundles understands that every entity is a complex, infinitely decomposable compound of heterogeneous properties. In these terms, we can say that one of the versions of bundle theory is the ontology of assemblages developed by Gilles Deleuze and Félix Guattari (1980). In a way that is similar to the conception of bundle, Deleuze and Guattari understand that everything is an assemblage that, at the same time, composes larger assemblages and is composed by smaller ones. In other words, all existing entities are assemblages, that is, encounters of different properties that, when assembled, assume an always transitional and changeable identity. In this sense, the identity of an entity emerges from the assemblage of the heterogeneous properties that composes it. In their turn, these properties are the result of other assemblages of different properties and so on. Therefore, the identity of an entity strictly depends from the assemblage of the differences that constitutes it.

There are also attempts to use the idea of process with fundamental ontological category. For an ontology of processes, the entities that make up the world are not static; they are not substances, but processes, becomings, which, in this way, have a history, constantly change. In spite of accepting movement, the notion of process supposes the idea of an evolutionary continuity, of infinite progress, that would cross the history like a thread of Ariadne underlying all transformation. This is a last residue of substantiality, which the ontology of processes is not able to get rid of, despite its disapproval of the substance category.

Of course, this brief survey of the most important theoretical frameworks in the so-called ontological turn of contemporary philosophy leaves many aspects out. Anyway, it already enables us to understand that the ontology of events differs from all such approaches, although it is closer 
to an ontology of assemblages. However, what does an ontology of events consist of? This is what we will see next.

\section{The ontology of events}

Let us start from zero: what is an event? Trying to formulate a minimal definition, Zizek writes:

An 'Event' can refer to a devastating natural disaster or to the latest celebrity scandal, the triumph of the people or a brutal political change, an intense experience of a work of art or an intimate decision. [...] This is an event at its purest and most minimal: something shocking, out of joint, that appears to happen all of a sudden and interrupts the usual flow of things; something that emerges seemingly out of nowhere, without discernible causes, an appearance without solid being as its foundation $(2014,8-10)$.

Additionally, the term "event"2 can be understood as a basic ontological category. According to an ontology of events, certain entities, which have the character of an event or an eventual nature, populate the world. What does that mean? In the first place, as an event, an entity is not a substance, nor an essence, but a flux. In the second place, insofar as it is an event, an entity is not a continuous process, but an interruption, a discontinuation. In the third place, strictly speaking, an event is not a singular entity, but certain a combination of heterogeneous properties, an assemblage, in the sense of Deleuze and Guattari (1980).

However, we should not conceive any assemblage as an event. Not everything that exists is of the order of an event. In an ontological sense, events do not correspond to the totality of reality; reality is not the sum of all events. Unpredictably and unexpectedly, events break the thread of reality, blasting the "continuum of history", to use an expression of Walter Benjamin $(1991,701)$. To conceive the event as the only and sufficient ontological category would be to fall into a trap. Without a doubt, knowing how to avoid this trap means a theoretical advantage. Stating that not everything is an event, the ontology of events can to disengage itself, at least to some extent, in relation to the spikey problem of the totality and, at the same time, does not have to reduce itself to a regional ontology. Indeed, the event is not a region of being, but the anti-being. Nevertheless, this does not mean that the being does not exist. On the contrary, the idea is that there is the being (the totality of the entities) and there are events (extraordinary entities or, rather, occurrences). 
An event is a flux, not a substance. This implies that an event is neither the starting line nor the finish line of any actualization process. An event is the movement between these two lines, a middle that spreads itself from the beginning to the end. It is not what precedes, nor what succeeds change; it is the change itself. Its reality is not that of a substance capable of remaining fixed, but that of an intermittent, infinitely changing flux. Thus, with the concept of event, change itself becomes an ontological category. It is not the only one, but it belongs to the basic entities that populate the world. This conception of change is a relevant theoretical gain of an ontology of events. For a long time in the history of Western thought, change has been one of the main stakes in the ontological discussions, but as a stone in their way. Let us just recall that, on the one hand, the main criticism against substantial ontology objects precisely its inability to think change. On the other hand, ontologies of processes, which criticize the ontology of substance, carry out the fundamental pretension of having an account of change and movement to provide. In short, since the ontology of events brings the notion of change to the condition of basic ontological category, it is a radical mobilism.

In addition, an event is something that seems to happen out of nowhere, something that simply happens - il arrive, say the French - , that is, something whose cause cannot be identified. It is completely unpredictable, since we cannot predict when or how the event will occur. It is completely unexpected because we cannot expect the event to occur in this or that way. There are no coordinates for the beginning, nor for the end of an event. An event has no coordinates; it is the total absence of coordinates. Thus, an event is something that breaks with all causality, an effect without cause, an effect caused by nothing. With this, we approach Zizek's $(2014,12)$ definition according to which an event is "an effect that seems to exceed its causes [...] an occurrence not grounded in sufficient reasons". The cause of an event can be determined, but only a posteriori, retrospectively, after the effect, after the event. There is here a reversal of ordinary causality (cause $\rightarrow$ effect), with the effect causing the cause (effect $\rightarrow$ cause).

Another relevant notion in an ontology of events is that of coordinates of reality. Zizek (1988) assumes - and this is his major assumption - that there are certain coordinates, which constitute the framework of the ontology that we, explicitly or implicitly, accept. The multiple combinations between the coordinates make possible and condition our reality. From the political point of view, ideology determines the coordinates. From the psychological point of view, fantasy determine them. Thus, we can say that, in the first place, these coordinates are 
transcendental, in the sense of German idealism. "'Transcendental' is the philosopher's technical term for such a frame, which defines the coordinates of reality" (ZIZEK, 2014, 13). The coordinates are of second order and, therefore, they have a nature, which is different from that of intramundane material entities. In the second place, coordinates are not entities, nor substances, nor processes, nor bundles. Moreover, coordinates are not assemblages. Nevertheless, the way in which they combine, the specific assemblage they entertain is always decisive for the production of an event. In the third place, coordinates are not events, although events may emerge from a certain combination of them.

From the temporal point of view, although they are a priori, since they precede the events, the coordinates are historical. As the frameworks on which our understanding of reality is based change throughout history, we can say that a certain configuration of these coordinates corresponds to the historical a priori (FOUCAULT, 1969) of a certain period of history. We can define an historical a priori as a configuration of the coordinates that determine reality. As such, this configuration precedes the occurrence of the events and may even awaken them. However, precisely the occurrence of actual historical events modifies this a priori. In other words, a historical a priori is a priori because it determines the events and is historical because the events determine it.

From the spatial point of view, the coordinates are, of course, territorial landmarks. There is a kind geography of events here. A coordinate assemblage corresponds to a map that precisely describes a territory. In this sense, a territory is a space of thought demarcated by a certain set of coordinates. We can say that this is the scope of effectiveness of such coordinates. Thus, on the one hand, each set of coordinates demarcates a territory and each territory matches a specific reality. Moving from one territory to another, varying the conceptual framework, changing the set of coordinates is the same as moving from one reality to another. On the other hand, the sets of coordinates are subject to constant movements of territorialization and deterritorialization (DELEUZE; GUATTARI, 1980). This means that the boundaries between territories are not fixed. On the contrary, they are always shifting, so that a coordinate assemblage can never petrify. In this way, each territory can exert some influence over other territories. The sets of coordinates suffer the impact of the movement of expansion and retraction of territories. Indeed, there is a kind of tension among them. This is extremely important for us because it supposes an agonistic perspective, according to which the inter-territorial space is a battlefield. In other words, the ontology of events seems to presuppose the existence of a certain type of struggle between the conceptual frameworks. 
Historically and geographically changeable, the coordinates, or rather, the specific configuration of the correlation of forces, the assemblage between them is subject to what we can call breakdown (HEIDEGGER, 1967). Throughout history, innumerable frames of reference, conceptual schemes, epistemes died, and so many others were born. Each time, it was necessary that an event occurred to destroy some coordinates and put other coordinates in the place of the previous. As Zizek $(2014,24)$ claims: "at its most elementary, event is not something that occurs within the world, but is a change of the very frame through which we perceive the world and engage in it". Thus, by breakdown of coordinates, we should understand a revolutionary event, an epistemological rupture, the deconstruction of a paradigm. Nevertheless, there is no deconstruction of coordinates without construction of other coordinates, or yet, without another coordination of coordinates.

Furthermore, the shift of coordinates has not only second-order or transcendental effects; its effects are very real and in real. As the coordinates through which we perceive something as real change, so the reality of this thing itself changes because the change in our coordinates forces us to think, act, and intervene differently in relation to this thing. At the same time, conceptual transformations that operate on the side of the subject presuppose and imply real transformations, which take place on the side of the object. Both forms of transformation, transcendental and real, subjective and objective, are integral parts of the same event, of the same breakdown of coordinates. In Zizek (2014), the concept of event is clearly post-Kantian, since it dialectizes the typical dichotomies of modern philosophy: knowledge and being, subject and object, phenomenon and thing-in-itself, epistemology and ontology. Indeed, we can say that it recognizes problems in all of them, which stem from one-sided assumptions. In relation to these binary oppositions, the concept of event occupies a synthetic position, or yet, a higher composition; it composes both sides. Therefore, to the extent that it is necessarily an event, the breakdown of coordinates does not have only a discursive, but also a material dimension.

\section{Violence and parallax}

In general, we perceive a breakdown of coordinates as a violence. Let us say that the change in the basic functioning of the existing order, the interruption of the ordinary flux of things, the disturbance in the way things normally go, all this has to constitute some form of violence. This form of violence is not physical - it is not the same as killing, nor aggressing, nor 
torturing, nor raping etc. -, but it is still a form of violence. In a sense, we should say that the violence contained in the breakdown of the coordinates of reality is much more intense than physical violence because it does not turn against something in the world, but against the very conditions of possibility of the existence of something. If it is possible to measure the degree of violence of an occurrence, its gravity, its offensiveness, its impact, we have to admit that there is a sensible difference between annihilating something and eliminating the very possibility of the existence of something. It seems clear that the last case is more serious because it characterizes a more intense of form of violence.

The breakdown of coordinates involves what Zizek calls parallax, that is, the change of perspective that produces the modification of the object itself. In other words, parallax is the displacement of the point of observation that causes the displacement of the observed thing. Thus defined, it is a notion, borrowed from astronomy by Zizek, which helps to visualize the breakdown of coordinates.

The standard definition of parallax is: the apparent displacement of an object (the shift of its position against a background), caused by a change in observational position that provides a new line of sight. The philosophical twist to be added, of course, is that the observed difference is not simply "subjective", due to the fact that the same object which exists "out there" is seen from two different stances, or points of view. It is rather that [...] subject and object are inherently "mediated", so that an "epistemological" shift in the subject's point of view always reflects an "ontological" shift in the object itself (ZIZEK, 2007, 17).

We should remark that the concept of parallax is close from that of shift of perspective (Perspektivenwechsel), formulated by Friedrich Nietzsche (1980), for whom, a new perspective can produce a new world, as well as a new name can produce a new thing. According to Nietzsche's (1980) perspectivism, "there are no facts, only interpretations". The idea here is that not only knowledge has the nature of a perspective, but the world itself or, rather, every entity is an interpretation and a perspective. Perspectivism is not a subjectivism because the subject is just another interpretation in a world, which is an amalgam of interpretations. This is why the displacement of perspective, the change of the interpretation, the modification of conceptual framework is a very effective way to transform the world. Transformation that is, at the same time, subjective and objective, epistemological and ontological, in the words and in the things. 
Similarly, an effective parallax itself constitutes a genuine event. With this, Zizek adds something that is not explicitly in Nietzsche.

By definition, parallax is violent and, in a sense, it is even the most intense form of violence that can occur. Suppressing or changing the coordinates based on which a subject thinks and acts, thereby altering his reality, no doubt, is something that destabilizes and disorients, producing a sense of emptiness, a feeling that there is no ground anymore. It is the paralytic violence, which is characteristic of the breakdown of coordinates. However, the breakdown of coordinates is not just of the order of deconstruction. Parallactic violence is not only negative; it is rather a negation of negation. Then, it is also positive, in the sense that it affirms and produces something. Thus, as a shift of perspective, parallax does not only destroy, but also builds or makes possible a new construction. Therefore, the parallactic violence of the breakdown of coordinates implies opening up a new space of possibilities, launching other possibilities, virtualizing again reality.

Nevertheless, the breakdown of coordinates is not just openness, nor is a delirious flux of deterritorialization toward a schizophrenic nomadism and a Dionysian laceration. This is a lesson of German idealism, from Fichte to Heidegger: one does not destroy (abbauen) a territory, without constructing (bauen), on the liberated terrain, a new correlation of coordinates. In other words, a movement of reterritorialization follows the deterritorialization, which is characteristic of the breakdown of coordinates, and recombines them, producing a new assemblage, a new territory. The pivot of this oscillation, the turning point between territorialization and deterritorialization of the coordinates is, precisely, the concept of event. The breakdown of coordinates is an event and, as such, it is doubly violent, not only as destruction, but also as construction. We should insist on this: there is violence also in the construction of a set of coordinates. Indeed, this is the extreme point that something can reach on the scale of violence. As Zizek $(2014,46)$ says: "here we reach the limit of event as reframing: [...] the event is no longer a mere change of frame, it is the destruction of frame as such".

To synthetize, we can say that, throughout collective or individual history, certain events occur, which radically modify our political ideologies and our unconscious fantasies in an unforeseeable and unexpected way, transforming from the base the transcendental coordinates, based on which we think as we think and act as we act. These transformations of coordinates (second order) obviously cause transformations also in the factual reality (first order). Now, such transformations, the annihilation of old coordinates and related ways of thinking and acting, the production of 
new coordinates in the liberated field, the changes introduced into reality by the definition of new coordinates, all these processes imply a kind of violence. Violence of transformation, violence of annihilation and production of coordinates, violence in the transcendental and in the real, violence of parallax, violence of the event: it is about this type of violence that, as Zizek would say, is necessary to speak without moralism, without mystification, without fetish.

Now, we will take some examples, which we believe to be as concrete as possible, of what has been designated here as violence of event, as breakdown of coordinates, as parallax. However, before analyzing the examples, some further general explanation is required. Referring to these examples has a practical purpose; it performs a certain function in the pragmatics of events. The ontology that is presupposed here confers a special role to thought. The idea is that thought cannot be just a description of the events, no matter how accurate and justified is can be, it has also to perform the task of critique. In such a context, critique is a propaedeutic of events. It is what we need to know before and in order to occur an event. In this perspective, critique is a strategy of events production, which seeks to make possible a passage from discourse to act, that is, an eventual acting out. This is how critique can be not reactive, but active. In short, the task of thought is to incite events, to activate them, to provoke them, to accelerate them, and this by the means of a critique of our reality and of its coordinates.

As Bertolt Brecht would say, examples can play a political-pedagogical role, namely, to lead the recipients of critical discourse to exert critique by themselves, contaminating them with its germ and interpellating them to take a position. It is precisely here that the critical analysis of the coordinates of reality becomes a strategy to produce events. Thus, the pragmatics of events, that is, an analysis of the events that seeks to produce them, shows its political dimension. In this way, not only critique, but also the imminence of an event, which the critique tries to accelerate, forces all the concerned to take a political position. In this context, nonpositioning is already a position, as occurs whenever we are faced with an event of historical effective significance, that is, with a properly political event. Therefore, the breakdown of coordinates is an aim, a political challenge on symbolic level that has real consequences. We should say that this aim marks what we should call critique.

\section{Bartleby, the critic}


To begin with, let us take an example from a short story by Herman Melville (1853), namely, Bartleby, the Scrivener. Although it comes from the literature, this example has strong philosophical implications. This is why it was interpreted by several authors - Camus, Deleuze, Negri, Agamben -, who drew from it their own reflections and made of it an example of their own ideas. As we will see in a while, Zizek (2007) also has his interpretation.

Let us consider the storyline. The protagonist - which is, indeed, an antagonist, or rather, an agonist -, Bartleby, is a young accountant scrivener hired by a Wall Street lawyer. In a first moment, Bartleby performs all the tasks entrusted to him in a very diligent and efficient way, even going beyond the requests. However, one day, when his boss asks him to copy a document, he simply replies: "I would prefer not to". Then, Bartleby reacts to all demands and orders made to him in the same way: "I would prefer not to". On several occasions, the boss tries to understand his attitude, but he just repeats: "I would prefer not to". At one point, the employee no longer does any task, but even so, the boss does not fire him. Interestingly, Bartleby had acquired a strange power over his boss, who ultimately wants to protect him and save him, including from himself.

Contrary to the autobiographical interpretations, the story is not a diary. Contrary to most of the clinical analyses, its theme is not depression. Above all, Bartleby, the Scrivener has a political meaning. The narrative turns around a power relation between employer and employee. In a sense, it is a metaphor of the class struggle between capital and work. As a status quo, all the coordinates are set; the demarcation of territory is unmistakable. The work contract clearly defines who orders, who obeys, what kind of orders can be made, what kind of tasks can be ordered etc. Under these conditions, everything unfolds as planned, without getting anything under nor above the expectations. However, suddenly and surprisingly, everything is disorganized, or yet, deterritorialized by an event, whose cause cannot be identified. From day to night, everything changes. All the ready and calculable schemes begin to dismantle. We can say that an element leads to the breakdown of coordinates here, altering the given reality, namely the answer that Bartleby insists on repeating: "I would prefer not to".

The singularity of this answer is that it deconstructs the question. Here is its political significance. In general, what is expected is that every request from a boss, according to the agreed rules, will find a "yes" as answer. It may also get a "no" as answer, but this breaks the contract of work and violates the established hierarchy. Paradoxically, Bartleby's answer does not fit into this alternative. "I would prefer not to" neither 
means "no" nor "yes". The boss does not know what his employee is going to do anymore, he simply does not know what to expect. The power relation between employer and employee, capital and work reverses itself. The worker starts to exert a strange domain over the boss. In Zizek's $(207,382)$ words, Barteby's attitude is a parallax. About that, he writes:

[...] the first truly critical ("aggressive", violent) step is to withdraw into passivity, to refuse to participate - Bartleby's "I would prefer not to" is the necessary first step which, as it were, clears the ground, opens up the place, for true activity, for an act that will actually change the coordinates of the constellation (ZIZEK, 2007, 342).

The point is that, in a sense, Bartleby's attitude is violent. His answer is not simply passive, although it is peaceful, since it does not imply, in the first place, material destruction or bloodshed. Its violence is of second order because it touches the coordinates, the template, or the presets, without which the boss' requests would not make sense. Thus, its force, its impact, its power of destruction is much greater than that of any act of physical violence. Bartleby's violence has power enough to provoke an event. Authentic pacifism does not reveal itself as non-violence, but as a kind of violence $^{3}$ against violence, the negation of the negation. It is capable of breaking the chain of violence that only leads to more violence, since it blocks the process of sedimentation of the coordinates and their correlations and leads to another possibility, to an open space, to a void, where something else than violence can emerge.

In other words, when violence becomes the rule, pacifism can be a strategy of change; it is the violence, which the situation requires. This why we can say, and this is the most important for us, that Bartleby is not a mere pacifist; indeed, he is an agonist, who searches for a shift of perspective, inciting a breakdown of coordinates, and activating an event. In this sense, pacifism is not a form of irenism nor of consensualism, since an agonistic disposition drives it. For instance, a disposition for struggle, for resistance, and for transformation characterizes Bartleby's pacifism. Above all, this is not a way to elude conflicts, but a strategy to overcome them. Therefore, we have to do with a kind of pacifism of attack, an agonistic pacifism. As Hegel would say, here is a notion that makes a synthesis of opposites. In what follows, let us look at some more examples in the same vein.

\section{Agonistic pacifism (Socrates, Jesus, and Gandhi)}


When the question is violence, one of Zizek's (2009) favorite examples is Mahatma Gandhi. Provocatively, Zizek compares him to none other than Adolf Hitler. The provocation consists in stating that the procedures of the Indian spiritual and temporal leader were more violent than that of the chancellor of the Third Reich. On the one hand, we can say that this is because Hitler's violence was, to employ Nietzsche's terminology, reactive, that is, incapable of constructing anything. It was an form of "actualized nihilism" (DELEUZE; GUATTARI, 1980). In this respect, let us just mention that Nazism is biopolitics (production of life) becoming tanatopolitics (production of death) (FOUCAULT, 1997). The latter is a gigantic bulldozer, which eventually ran over all German people, the Nazi high bureaucracy, and the Führer himself. Zizek claims that Hitler feared that something would really change. At the end of the day, Nazism demonstrated that it was a desperate attempt to save capitalism from a supposedly terrible communist spectrum.

On the other hand, Gandhi would have been more violent than Hitler was because the latter led Germany into the abyss and darkness. On his turn, Gandhi practiced the Satyagraha, that is, a principle of non-aggression and a non-violent form of protest. Indeed, he introduced the practice of Satyagraha as a revolutionary strategy, using tactics such as strikes (including hunger strikes), boycotts and blockades of the general functioning of the economic and political apparatuses of the colonial State. In this way, he decisively contributed to build the conditions for the independence of the modern Indian State. If it makes sense to say that Hitler's violence is intense because it is a kind of destructive destruction (a negation), then the violence of Gandhi's pacifism is more intense and, consequently, more violent because implies a kind of destructive construction that is, at the same time, a constructive destruction (a negation of a negation). In short, it Gandhi's pacifism is not characteristic of a pacific pacifist, but of a warrior pacifist that is also a pacific warrior.

Another extraordinary example in this sense is that of the "father of philosophy", Socrates (ZIZEK, 2014,67). We can say that, as well as his ignorance was a higher form of knowledge, his non-violence was a more elevated form of violence. Socrates was able to put an end to the chain of acts of first order violence, by the means of an act of second order violence. In this way, for Socrates, the acceptance of his own condemnation and the self-execution of his penalty (drinking hemlock) were a kind of resistance and a strategy to break up with absurd coordinates. Here again, when the exchange of aggressions becomes the rule, the only way to stop it is do not retaliate. We know that this is an old story. The originality of the present 
approach lies on considering that not retaliating, instead of being a nonviolent way of stopping violence, is a more intense form of violence. This is not simply an elimination of violence, but its intensification to the point where it dialectically cancels itself. Thus, not only because Socrates used to challenge and defeat the sophists, his enemies, he was an agonist. Maybe, his trial is the most classical example of a reversion of an unfavorable argumentation game. In Socrates' strategy, the main target was not the claims of his adversaries. Therefore, he did not want to contest them, but law itself and its use. At the end of it all, for history, the effective condemned was not the defendant, but his prosecutors and judges. The violence he applies to himself was not reactive, but moved by an agonistic disposition and directed against his detractors. In short, Socrates was not a coward, but a fighter.

Finally, let us take Jesus as an example. In his talks, Zizek $(2014,67)$ likes to quote the passage in the New Testament in which the son of God says: "Do not think that I have come to bring peace to the earth. I came not to bring peace, but the sword" (Matthew, 10:34). "I came to set fire to the earth" (Luke 12:49). Passages like these are proof that Jesus' conduct, sometimes, could be violent. Thus, "turning the other side", "throwing the first stone", "giving Caesar what belongs to Caesar", "Father, forgive them, they do not know what they do" are not signs of subservience nor of surrender. Indeed, the Bible is full of cases like that. They are gestures of extreme violence, the only capable of breaking the coordinates of the violence reproduction, that is, the chain in which an aggression responds another aggression. These gestures give us a lesson on how to reverse the coordinates. They teach us the parallax: to love not himself, but the other, to love even our own enemy. In this sense, love is violence because both mean the destabilization of the coordinates according to which the aggressor operates. In short, love is violent. About the violent nature of love, Zizek says:

[...] if we marry today, it is more and more in order to renormalize the violence of falling in love, the violence nicely indicated by the Basque term for falling in love - maitemindu - which, literally translated, means 'to be injured by love'. It is also for this reason that finding oneself in the position of the beloved is so violent, even traumatic. $(2014,133)$

Love injuries; it is traumatic and violent. This is why we do not ascend, but fall in love. For example, the violence of love can destabilize even an aggressor, coercing him into reflection and self-awareness, which remove 
the meaning of the aggression and dissuades the practice of the violent act. However, a strategic use of Jesus does not avoid a certain type of violence, eventual violence, transcendental violence, which can alter the very conditions of possibility of the occurrence of violent actions. Concretely, this violence is love in what it has of a breakdown of coordinates. As a result, we can say that, like Gandhi and Socrates, Jesus is also an agonistic strategist.

Nevertheless, we still have not addressed one of the announced questions, namely, what about the left-wing political thought in the present global scenario? Let us just say that Socrates, Jesus and Gandhi, as well as Bartleby, are names for exemplary strategies of resistance. Nowadays, in order to reinvigorate itself, left-wing thought can and should appropriate and deepen examples like these. In other words, what we need to live is not an ideology - this we have ever had -, but a strategy. As a strategic device, left-wing would be able to catalyze the activation of an event that can start a new history. However, this will only be possible when it realizes the necessity of the political use of a violence that explodes the continuum of a history that supposedly has already ended.

\section{From antagonisms to agonistics}

Obviously, in spite of all its merits, Zizek's approach is not immune to criticism. Therefore, we could not finish, without saying some words in this respect. In our view, he is wrong, at least, in one point and, with this, we want to say that one of his most important theses is false. It is of his main thesis on antagonism. About this, he writes, for example:

[...] while here every provisional, temporarily successful solution of a particular problem entails an acknowledgement of the global radical deadlock, impossibility, the acknowledgement of a fundamental antagonism. My thesis [...] is that the most consistent model of such an acknowledgement of antagonism is offered by Hegelian dialectics [...]. (ZIZEK, 1989, XXIX)

Why does Zizek get wrong the problem of the antagonism? In short, because of the prominent role that dialectics plays in his thought. We can say that, on the one hand, this perspective is right in acknowledging the existence of a fundamental kind of antagonism, which is the propeller of dialectic and which applied analyses based on it are right to presuppose. However, on the other hand, it is wrong because it thinks every antagonism of positions as a contradiction, which a synthetic superior position 
(Aufhebung) will resolve in an all-encompassing reconciliation. From a dialectic perspective, we could reply this criticism saying that we should think the antagonism as integral part of the core of this synthesis and the void as immanent to the Absolut. In any case, the theory of internal contradiction remains consistent with the idea of a universal Aufhebung, which is precisely what we cannot accept. Now, as we saw, according to Zizek, this would be the best approach to the problem of antagonism.

We are not convinced of this. In our opinion, dialectic is not the best way to think about contradiction because it reduces agonistics to antagonism and, doing this, it tries to domesticate the differences. Thus, it miss the opportunity to think tensions, struggles, power relations and games of forces, that is, difference in its effective materiality. Indeed, dialectic is particularly misleading. We can say that it saw the problem, but missed the point. This allows us to make explicit one of the methodological procedures that have been in use here. In our reconstruction of Zizek's position, we have deliberately not approached his main reference, namely, Hegel. In general, we believe that it is possible to reach very similar conclusions to Zizek's, with which we agree (inclusive about Marxism and psychoanalysis), without having to assume the same premises. Without mentioning Hegel in our reconstruction, we have wanted to suggest it. Anyway, his ability to infer those conclusions from these premises is outstanding. For us, this kind of talent is out of question.

Besides that, we have also reasons to believe that another perspective, closer from Nietzsche's (1980) ontology of the will power and from Deleuze's (1962) theory of forces, is able to provide a more interesting account of this "fundamental antagonism", but then it will never be object of a great synthesis. Let us put things as follows. To figure out the complexity of reality in its unspecific difference, we do not need a macronarrative (it does not matter how complex it can be). What we need are not systematic treatises, but experimental essays. We need thousands of micronarratives, infinite perspectives, an indefinite multitude of small eyes, the only capable to see difference wherever repetition prevails, or yet, to perceive the beginning of an antagonism whenever the end is reconciliation. In the last instance, there is no Aufhebung because there is not a last instance. This perspective is not dialectic, but agonistic, since it keeps the contradictions theoretically opened, conceiving them as tensions, as relations of force, in a word, as difference. In conclusion, we can say that more than antagonism, dialectics misses agonistics, and this is very clear in its approach to the problem of difference. We are fully aware that this hypothesis requires argumentation, and we will do it, but elsewhere. 


\section{Notes}

${ }^{1}$ Professor dos Cursos de Graduação e Pós-graduação em Filosofia da Universidade Estadual do Ceará. Doutor em Filosofia pela Universidade Federal do Ceará.

2 "Ereignis" in German, "évènement" in French, "acontecimiento" in Spanish, the term "event" is difficult to translate. In English, it has "happening" as synonym.

3 This is precisely what Walter Benjamin denominated divine or pure violence: "If mythic violence establishes law, divine violence annihilates law; if the former establishes boundaries, the latter annihilates without limits; [...] if the first is threatening, the second strikes; if the former is bloody, the divine is lethal in a non-bloody way [...] For blood is the symbol of mere life. [...] with the mere life, ends the dominion of law over the living. Mythical violence is bloody violence exercised, in its own favor, against mere life; divine and pure violence is exercised against all life, in favor of the living." (BENJAMIN, 1999, 200-1). 


\section{Bibliography}

BENJAMIN, Walter. Über den Begriff der Geschichte. In: BENJAMIN, Walter. Gesammelte Schriften, vol. I.2. Frankfurt a. M.: Suhrkamp, 1991.

BENJAMIN, Walter. Zur Kritik der Gewalt. In BENJAMIN, Walter. Gesammelte Schriften, vol. II.1. Frankfurt a. M.: Suhrkamp, 1999.

BRYANT, Levi; HARMAN, Graham; SRNICEK, Nick. The Speculative Turn: Continental Materialism and Realism. Melbourne. 2011

DELEUZE, Gilles. Nietzsche et la philosophie. Paris: PUF, 1962.

DELEUZE, Gilles; GUATTARI, Félix. Capitalisme et schizophrénie: Tome 2, Mille plateaux. Paris: Minuit, 1980.

FOUCAULT, Michel. Il faut défendre la société . Cours au Collège de France (1975-1976). Paris: Seuil/Gallimard, 1997.

FOUCAULT, Michel. L'Archéologie du savoir. Paris : Gallimard, 1969.

FUKUYAMA, Francis. The End of History and the Last Man. New York: Free Press, 1992.

HEIDEGGER, Martin. Sein und Zeit. Tübingen: Max Niemeyer, 1967.

MELVILLE, Herman. Bartleby, the Scrivener: A Story of Wall Street. New York: Putnam's Magazine, 1853.

NIETZSCHE, Friedrich. Kritische Studienausgabe, vol. 12. Berlin/New York: Walter de Gruyter, 1980.

RANCIÈRE, Jacques. La haine de la démocratie. Paris: La Fabrique, 2005.

ZIZEK, Slavoj. "Disputations: Who Are You Calling Anti-Semitic?" The New Republic, 2009.

Avaible on: https://newrepublic.com/article/62376/disputations-who-areyou-calling-anti-semitic.

ZIZEK, Slavoj. Le plus sublime des hystériques: Hegel passe. Paris: Point hors ligne, 1988.

ZIZEK, Slavoj. Living in the End of Times. London/New York: Verso, 2011. 
ZIZEK, Slavoj. Mapping ideology. London/New York: Verso, 2012.

ZIZEK, Slavoj. The Event: Philosophy in Transit. London: Penguin, 2014.

ZIZEK, Slavoj. Parallax View. Cambridge: MIT Press, 2007.

ZIZEK, Slavoj. The Sublime Object of Ideology. London/New York: Verso, 1989.

ZIZEK, Slavoj. Violence: Six Sideways Reflections. London: Picador, 2008.

Received/Recebido: 05/10/20

Approved/Aprovado: 18/10/21 